\title{
EAST ASIAN DEVELOPMENTAL PATH AND LAND-USE RIGHTS IN CHINA ${ }^{1}$
}

\author{
Ganesh K. Trichur \\ The Brecht Forum \\ New York, NY 10014 \\ gtrichur09@gmail.com
}

\begin{abstract}
This paper highlights contemporary China's long-term continuities with the historical East Asian developmental path in relation to its post-1978 revival of market-economy traditions. The revival of market economy traditions does not exemplify the unfolding of processes associated with the "one-size-fits-all" Washington Consensus. Rural land reforms were driven from below and strongly influenced policy changes from above. Neither rural nor urban land use relations suggest a more general unfolding of neoliberal processes of capitalist accumulation by dispossession. Contemporary Chinese land relations reflect the effects of continuities with historical East Asian regional traditions more strongly than do some discontinuities and ruptures that emerged in the conjuncture of the mid-1980s. These continuities remain more important in understanding the future of the China-led East Asian region. Like the Ming and Qing dynasties, China's Party-State is sharply focused on problems of governance. Retaining legitimacy and recreating a welfare state to promote harmonious development rather than growth fetishism appears to characterize China's current trajectory.
\end{abstract}

\section{INTRODUCTION}

In this paper I relate the historical traditions that underlie an East Asian developmental path with the evolution of land use rights in post-1978 China. Marxist analysts like David Harvey (2005) claim that post-1978 land relations in China exemplify a more general unfolding of neoliberal processes of capitalist "accumulation by dispossession" from the land. I argue that although the neoliberal period facilitated China's re-entry into the capitalist world-economy, China's subsequent development unfolded by and large on its own terms and by its successful use of the U.S.-led neoliberal turn of the late 1970s and beyond for its own purposes, which had little use for the "one-size-fits-all" neoliberal Washington Consensus. On the contrary, post-1978 land relations in China reveal more continuity with general East Asian traditions than do some of the ruptures with East Asian land-use traditions that emerged after the mid-1980s. These discontinuities were a consequence of China's opening its doors to foreign industries and their environmental downsides. Western industry wanted to relocate to China to increase profits from

\footnotetext{
${ }^{1}$ I would like to thank Marina Karides and Farshad Araghi for their incisive comments and suggestions, which have improved the quality of this paper.
}

Copyright @2012, American Sociological Association, Volume XVIII, Number 1, Pages 69-89 ISSN 1076-156X 
capital accumulation. Nevertheless, China selectively allowed relocation of foreign capital into its coastal zones, and it did so only after these coastal zones had benefited from investments made by Overseas Chinese capitalist diaspora in Hong Kong and Taiwan.

The long-term outcome of these and other decisions, which began to crystallize after the IMF lost credibility due to its role in the 1997-8 East Asian financial crises, enabled China to carve an autonomous approach to East Asian regional development independent of Washington. As Bin Wong argues in the context of the rising role of the renminbi in cross-border East Asian trade, "Washington is no longer in a position to limit the ways in which Chinese and Japanese develop financial markets in East Asia" (Wong 2011:160). Contemporary migrant workers' struggles against exploitation in China's eastern coastal economic zones and unemployed workers' struggles for livelihood in the aftermath of the restructuring of the State-owned Enterprises (SOEs) in China are often claimed as evidence for the effects of processes of accumulation by dispossession promoted by neoliberal states following the Washington Consensus (Harvey 2005).

These claims, however, do not acknowledge the strong influence of historical East Asian regional traditions on late-Imperial and contemporary China. Nor do they take into account durable challenges of governance encountered by all of China's political rulers, whether in lateImperial times (Wong 1997), in the time of the post-1949 People's Republic, or during the post1978 phase of economic reforms. As Giovanni Arrighi has underscored, almost unique to contemporary China is "the fundamental problem of how to govern and develop a country with a rural population larger than the entire population of either Africa, or Latin America, or Europe" (Arrighi 2007:374-5, emphases in original).

This fundamental problem may be seen as a larger historical problem of governance in an East Asian region whose center was Imperial China until the mid- $19^{\text {th }}$ century. A uniquely East Asian developmental path that was labor-intensive and efficient in its use of land emerged as a response to governance problems of land and labor under late-Imperial Ming and Qing dynastic rulers. The Chinese revolution in the course of the first half of the twentieth century, influenced by the Russian revolutionary path (Anderson 2010), did deviate from the East Asian developmental path. At the same time, China's peasant-based rural revolution and its leadership grafted new traditions onto the East Asian developmental path that addressed more effectively problems of governance of land and labor in a world dominated by U.S.-led Cold War politics. The post-1978 Deng Reforms revived many of the market economy traditions that were integral to the historical East Asian developmental path-suppressed during the Maoist years-thereby reinforcing Chinese continuities with that path of development.

Since the mid-1980s these continuities with East Asian traditions have come under strain as China's export-oriented growth engine drives world-systemic growth. But the continuities remain far more important in understanding the future of both the China-led East Asian region and the capitalist world-system. These combined and related futures of East Asia and the worldsystem are closely tied to the nature of China's development trajectory, and China's support for development in the global South. Insofar as the Chinese growth engine reproduces East Asian developmental lineages, it also presents possible alternatives to the notion that 'there is no alternative' to the U.S.-led neoliberal developmental model imposed on Third World states in response to the Southern debt crises of the mid-1980s. IMF-imposed neoliberal structural adjustment programs (SAPs) for countries whose debts were a direct outcome of the 1979-1982 Volcker monetary shocks undermined welfare states in the Third World. SAPs also destroyed the viability of the Third World as a political group in the interstate system and later unleashed 


\section{JOURNAL OF WORLD-SYSTEMS RESEARCH}

uncontainable social strains on the former Soviet Union (through shock therapies) and on some Eastern European societies.

China, by contrast, (re-)entered the world-system in 1972 from a position of relative economic and political strength. As Perry Anderson (2010) argues,

at the gateway to their reforms, perhaps the most decisive of all the differences between Russia and China lay in the character of their political leadership. In command of the PRC was not an isolated, inexperienced functionary, surrounded by aides and publicists infused with a naive Schwärmerei for all that was Western, but battle-hardened veterans of the original Revolution, leaders who had been Mao's colleagues, and had suffered under him, but had lost none of their strategic skills or self-confidence... Collectively, they were in a strong position, enjoying not only the prestige of their roles in the Civil War and building of the nation, but the popularity of having brought the Cultural Revolution to an end, which was met with a surge of relief in the cities. (77-8)

This collective leadership of the Party-State led by Deng Xiaoping did not follow the prescriptions of the Washington Consensus centered on indiscriminate deregulation, liberalization and privatization. As a consequence, China emerged relatively unscathed from the traumas of the 1997-98 Asian financial crises that devastated many of those national economies that followed IMF instructions. More importantly, the PRC's long revolutionary tradition of selfreliant economic development, context-specific domestic innovations, and a foreign policy commitment to self-determination make China's developmental path especially appealing to nations of the global South (Zhengyue 2010).

Although considerable rural-urban and inter-regional inequalities emerged in China after the mid-1980s, Chinese economic growth was also accompanied by substantial upward social mobility (Wright 2010). The re-creation of a welfare state on expanded foundations followed strong pressures from the urban working classes (see for instance Frazier 2010), and the second rural land reform of the late 1970s and early 1980s responded to strong pressures from farmers in the countryside. Present evidence suggests that the Chinese developmental path continues to respond to popular demands from below. The vision underlying the current $12^{\text {th }}$ Five Year Plan (2011-2015) is guided by principles of harmonious development that place less emphasis on growth per se (currently at around 9\% per annum) and more emphasis on growth balanced by redistributive considerations. The Plan harshly penalizes corruption at the local governmental levels. Such a vision does not accommodate the pursuit of neoliberal accumulation by dispossession, if only because social stability and economic development are key sources of legitimacy of rule by the Chinese Party-State. But can China become more than a poor people's welfare state? China's future stability depends on the extent to which the Chinese development path draws sustenance from earlier East Asian development traditions. It also depends upon the extent to which Chinese developmental interests are able to combine with the developmental interests of the global South at a time of crisis of Western models of development (Arrighi and Zhang 2009). In this context, China's foreign policy statement by Premier Wen is promising. China "welcome[s] the fast development of emerging economies, respect[s] different models of development," and offers "increase[d] help to least developed countries to enhance their capacity for self-development, and promote strong, sustainable and balanced growth of the global economy" (Wen Jiabao 2011). A robust China-led world developmental path also depends upon sustainable reproduction of Chinese growth and development patterns. Positive signs in this 
direction were signaled in the shift in priorities towards sustainable development at the turn of the millennium under the Hu Jintao-Wen Jiabao leadership. Part of this shift in priorities is towards more equitable and welfare-oriented rural and urban land-use relations that have for long been a well-defined feature of the historical East Asian Developmental Path.

In the first section I outline some of the key historical features of the East Asian development path that I claim continue to operate in the new millennium. The sections that follow look at the implications for this development path during the post-1978 changes in Chinese rural and urban land relations. While there are environmental challenges to the East Asian developmental path, these challenges have not yet displaced more durable East Asian environmental legacies.

\section{HISTORICAL FEATURES OF THE EAST ASIAN DEVELOPMENTAL PATH}

Kaoru Sugihara (2003a; 2003b) contrasts the nature of an East Asian developmental path from standard claims regarding the Western European developmental path. These claims see world industrialization as the simple outcome of a "chain of technological diffusion" that originated in Western Europe before spreading elsewhere. By contrast, Sugihara argues that between 1500 and 1820 a distinctive East Asian industrious revolution path developed independently of the Western path. More importantly it generated standards of living in the East that were at least comparable to, if not more favorable than, the Western developmental path. As China's population increased to 400 million by the end of the $18^{\text {th }}$ century, its economy also became much larger than European economies: England's share of world GDP was around 6\% in 1820 and Europe's share as a whole remained less than China's share of over 30\% of world GDP. What is underscored is how China, and Japan under the technological influence of China, managed to reproduce such a large population without serious downgrades in its standard of living (Sugihara 2003b:79).

This East Asian miracle resulted from the region's institutional and technological mechanisms for the full absorption of family labor, which were a response to land and natural resource constraints. The model mobilized human material power around community-based work ethics that absorbed labor, and employed labor-intensive technologies that privileged small-scale production based on the family farm as production unit. It also promoted flexible specialization by providing farmers with incentives to develop managerial and inter-personal skills. In short, fuller East Asian utilization of all existing labor resources in relation to available land points to a pattern of labor utilization at sharp variance with labor use patterns elsewhere. For instance, settler colonies in the Americas either forcibly exploited or eliminated Indigenous labor and imported Africans as slaves for work on large plantations for the accumulation of capital by European colonists. East Asia's small-scale family farm based land utilization patterns developed in tandem with rapid commercialization of agriculture and proto-industrialization. Many small innovations and many sideline market-based activities multiplied throughout the region. In China under the Song Dynasty and beyond, local, regional and trans-regional market exchanges proliferated to allow "spectacular increases in total productivity, as all the advantages of specialization that Adam Smith later analyzed so persuasively came into operation" (McNeill 1982:29). Bin Wong (1997:17-32) in fact characterizes economic development in late Imperial China as unfolding under predominantly "Smithian dynamics." Arrighi in turn points to these Smithian dynamics to underline the vibrant market-economy based lineages of East Asian development, as distinct from the lineages of capitalist development in the West (2007:40-96). 


\section{JOURNAL OF WORLD-SYSTEMS RESEARCH}

These lineages of market-based development combined with institutional transformations (the eighteenth century Chinese 'miracle') to not only create in China the largest domestic market economy in the world, but also to overcome what Elvin (1973) calls China's "high-level equilibrium-trap" (321-33, 353-9). Although markets were suppressed during the Maoist interlude (1949-78), the post-1978 Deng reforms effectively revived these market economy traditions to facilitate a twenty-first century Chinese miracle.

To these features of the East Asian developmental path we may add the role of Confucian ideology-a crucial mechanism of governance through consent-in cementing civilian dominance within late Imperial China. In sharp contrast to autocratic Russian imperial-state traditions since the mid- $16^{\text {th }}$ century-consolidated through coercive concentration of resources gathered from a huge territory, disciplining the elites, and violent dispossession and deep enserfment of the peasantry (Derlugian 2011:213-29)-the imperial tradition in China had always placed more emphasis on consent rather than coercion as an instrument of rule (Anderson 2010:69). Chinese statecraft generally viewed both the organized resort to armed force and capital accumulation through 'shrewdness in buying and selling' as violations of Confucian propriety. While private merchants were tolerated and even encouraged insofar as their activity served official ends, "to allow merchants or manufacturers to acquire too much power, or accumulate too much capital was as unwise as to allow a military commander or a barbarian chieftain to control too many armed men" (McNeill 1982:34-6). Rich merchants were prevented from becoming too rich, and imperatives of social stability promoted benevolent centralized governance that had no comparable counterpart anywhere in Western Europe, where constant competition for power between rulers was often pursued at the expense of livelihood rights of subjects - a circumstance that lay at the roots of systemic chaos in European history (see Arrighi 1994: Ch.1). By contrast, the late Imperial Chinese state pursued the ideal of benevolence in its rule on the grounds that good government required supporting the people and regulating their livelihoods. "There is no early modern European government equivalent to the late imperial Chinese state's efforts at dictating moral and intellectual orthodoxy... Early modern European states did not share the Chinese state's view that shaping society's moral sensibilities was basic to the logic of rule" (Wong 1997:97).

Moreover, late Imperial China's search for social stability led it to design policies that ensured regular supplies of necessities of various kinds, especially food. The Qing dynasty (1644-1911) created an elaborate system of food supply management whose centerpiece was "a granary system which stored several million tons of grain. Located mainly in county seats and small market towns, granaries represented official commitments to material welfare beyond anything imaginable, let alone achieved, in Europe" (Wong 1997:93, 97-8; see also Shue 2010: 46-51). In general, late-Imperial Confucian agenda for domestic order possessed a "fractal" quality: "at any level in late Imperial China we may find expressions of a Confucian agenda for social order." Officials at all levels accepted the same long-run welfare agenda for social order (Wong 1997:121). These long-run welfare agendas of Imperial dynasties prevented the formation of those synergies between military enterprise and commercial enterprise that were to take place in Europe between the fourteenth and nineteenth centuries (McNeill 1982:40). In turn, the absence of these synergies between capitalism and militarism were closely associated with the promotion, formation, and consolidation in nineteenth century Imperial China of the largest market economy in the world. More generally, the strong promotion of impulses of market economy prevented capitalist development from taking root in the mainland. Late Imperial statecraft effectively exiled capitalists to the outer rims of the East Asian interstate system; in 
doing so it also prevented capitalists from subordinating the general interest to their own class interest (Arrighi 2007:333-6). The invention of the Cultural Revolution at a later moment (19661976) would be used by Mao's leadership to prevent a bureaucratic caste from subordinating the general interests of the revolution to their own class interest. Anderson (2010: 69) suggests that the Cultural Revolution may in fact have "owed more to Confucian than to any Marxist notions of historical change". Such a suggestion complements Daniel Bell's observation that 'it is not entirely fanciful to surmise that the Chinese Communist Party will be relabeled the Chinese Confucian Party in a few years' (cited in Eberlein 2009:273). Relabeled as Confucian or not, the post-2002 Chinese Communist Party (CCP) leadership of Hu Jintao and Wen Jiabao remains not only publicly committed to socialism; it also appears to be responding attentively to the accumulating social stresses and strains from continuously high economic growth through a newer emphasis on cultivation of a "harmonious society."

Did East Asia's incorporation under $19^{\text {th }}$-century British hegemony change the laborintensive, resource-saving, market-based direction of its development? As Sugihara (2003a; 2003 b) argues, late $19^{\text {th }}$-century Japanese industrialization basically reactivated traditional Asian local institutions, which were later to emerge as modern corporations, and in the first half of the $20^{\text {th }}$ century the rest of East Asia followed suit. However, between 1830 and 1930 the East-West income and productivity gap widened in the West's favor as the West used its military superiority to forcibly incorporate large parts of the East within its "extroverted" capitalist developmental path (Arrighi 2007). How did East Asia's developmental path respond to its $20^{\text {th }}$ century incorporation under U.S. hegemony? Between 1955 and 1973 the Japan-led developmental path systematically introduced capital- and resource-intensive industries to Southeast Asian environments with cheap, disciplined, and skilled labor. This powerful fusion of Western capital-intensive technology and Asian human resources generalized high rates of economic growth across Japan and much of Southeast Asia. In China, by contrast, Cold War determinations not only isolated the PRC from the world market (1949-78), it also forced the PRC to invent distinctive revolutionary traditions. Although during the Yan'an phase of the Chinese revolution the CCP under Mao forcefully subordinated China's market-economy legacies, it also championed revolutionary innovations that later complemented and revitalized the legacy of China's industrious revolution during the post-1978 Deng reforms. These revolutionary innovations were based on a "two-way socialization process" in which the CCP both directed and was shaped by the aspirations and values of the mass of rural peasantry. The CCP's land reforms during the Yan'an phase made the peasants the solid basis for the socialist transformation of the countryside (Selden 1995:37-8). Peasant-based revolutionary traditions combined with the modernizing thrust of Marxism-Leninism to qualitatively upgrade the life expectancy, adult literacy, and basic welfare of the masses (Arrighi and Zhang 2009:21-3). These revolutionary legacies of 1949-78 combined with the post-1978 revival of market-economy legacies in the 1980s and beyond to make the PRC-led East Asian region a "hybrid" engine of world economic growth dominated by East Asian developmental traditions.

\section{CHANGING LAND-USE RELATIONS IN RURAL AND URBAN CHINA}

How do land rights and land use relations in contemporary China relate with these legacies of the East Asian developmental path? I consider this question first in regard to rural land rights and then in regard to urban land rights, before situating the question within the context of long-run environmental trends and transformations in China. I seek to show how China's land relations in 


\section{JOURNAL OF WORLD-SYSTEMS RESEARCH}

the course of the post-1978 Deng reforms did not encounter anything resembling the well-known crisis experienced by Third World developmental states that were forced into extensive privatization and liberalization. The rural land reforms remain a success story despite the proliferation of land disputes, and urban land relations have preserved the entitlements of urban dwellers despite the layoffs that followed the restructuring of state-owned enterprises and despite considerable urban land speculation promoted by local government officials and property developers. China successfully bypassed the processes of accumulation by dispossession that neoliberalism inflicted on a great part of the global South and the former Soviet Union. In doing so, China may also have helped speed up the crisis of the neoliberal model for world development.

\section{Rural Land Relations in post-1978 PRC}

In the late 1970s, the Chinese Communist Party (CCP) introduced a 'second land reform' that entailed extensive de-collectivization of agriculture. Massive state-directed and spontaneous internal migration combined with the introduction in the mid-1980s of special economic zones in the eastern coastal areas to mark a turning point in the world-system in general, and in China's political economy in particular. This was a turning-point in the sense that, unlike the rest of the global South where neoliberal structural adjustments of the 1980s devastated an indebted Third World, in China the mid-1980s marked the beginning of the sustained success of an export-led national and regional growth path accompanied by considerable upward social mobility for China's rural population. Upward social mobility was in part an outcome of increased physical mobility of rural migrant farmers: over 130 million rural migrants left the farms in search of nonagricultural jobs, and most were productively absorbed into the newly created small-scale township and village enterprises (TVEs) which were not privatized until the late 1990s (Lee 2010:60). The spurt in growth of farmers' nonagricultural sideline activities revived the market economy lineages of the East Asian developmental path. If the mid-1980s saw a "frenzied conversion" of land to nonagricultural uses (Ho and Lin 2004a:83), this happened mostly in China's eastern coastal provinces, "a region that has less than 10 per cent of China's territory but accounts for 22 per cent of its cultivated land and 39 per cent of its non-agricultural land" (Ho and Lin 2004b:760). Because the second land reform empowered farmers to raise productivity of farm land and levels of farm and non-farm incomes, the conversion of land to nonagricultural uses was not accompanied by any general dispossession of farmers from the land. Although all land in China is still owned by the State, the second land reform enabled the return to the farmer of the use-right to rural land through land-lease contracts in the form of the new Household Responsibility System (HRS). The hybrid tenure system that emerged out of these reforms did not privatize land ownership, but instead allowed private farmers the right to use land formerly held in common.

This second land reform itself was the outcome of a long period of rural class struggles between 1949 and 1978 during which Chinese farmers struggled against agrarian transformations that the CCP imposed upon the peasantry. Driven by Cold War geopolitics, these projects included the forcible collectivization of agricultural land for purposes of industrialization and strong restrictions on farmers' markets and farmers' mobility through the hukou (household registration) system. These measures yoked farmers to production decisions of large agricultural collectives whose surplus output was transferred to the industrial sector. As different scholars 
have pointed out (Zhou 1996; Solinger 1999), the 1949-1978 Maoist regime actively facilitated an urban bias and sanctioned an urban public goods regime at the expense of the rural sector.

Nevertheless, such forms of "primitive accumulation" never approached anything remotely resembling the processes of relentless accumulation through violent dispossession of the peasantry in the USSR in the late 1920s. The differences in mechanisms and consequences of Soviet and Chinese collectivization point to deep differences in the two experiences. The formation of people's communes during the 1958-1960 Chinese Great Leap Forward ${ }^{2}$ was never intended-as it was in the USSR-as an attack on the peasantry. Along with land reforms of 19471953, the 1962 "Four Fixes Movement" granted permanent ownership of labor, land, animals and tools to the production team/the natural village (Ho 2010:105). Unlike in the USSR, where police ferocity was instrumental in the liquidation of the peasantry, in the PRC "bureaucratic blindness" was the immediate cause of the disaster that followed the Great Leap Forward. In contrast to the USSR, in the PRC there was no comparable deep alienation of the peasantry in the countryside. "The countryside was not durably demoralized by the Great Leap Forward, village life in even the worst afflicted regions recovering with surprising speed," and rural society could recover from the traumas of the Great Leap all those "centuries of market impulses" that were integral to life in the countryside (Anderson 2010:67, 76).

Moreover, rural farmers' movements and farmers' ingenuity circumvented many of the Collectivist era's feudal and 'caste-like' regulations. Farmers in short succeeded in transforming China through the baochan daohu movement that forced from below, the formalization from above of the Household Responsibility System (HRS) in the late 1970s (Zhou 1996). This second land reform was 'as egalitarian as the first, but far more favorable to peasant production' (Anderson 2010:83). By the mid-1980s a nationwide Household Responsibility System (HRS) built in the form of contracts between state and rural farm households - was in place as the communes were broken up and small plots of land leased to households. These contracts were validated for fifteen years in 1984; in 1993 they were extended for thirty years; and in 1998 the Party-State legalized the contracts with households for another thirty years. Under the HRS, the state's long-term leases of farmland to rural agricultural households made farm households responsible for making a fixed payment of grain or other agricultural items at below-market prices to the state. After meeting this obligation, rural households were free to use or sell surplus produce in the market (Perry and Selden 2010:4-5; Wright 2010:110).

As farmers responded to the new incentives, agricultural productivity shot up and the farm economy realized a series of bumper harvests. Sideline activities multiplied as farmers redeployed their surplus work time from tillage into rural industry, lifting peasant incomes from $30 \%$ to $44 \%$ of national income between 1978 and 1984 (Trichur 2009:109-110; Anderson 2010:83). At the same time, restrictions on farmers' mobility-institutionalized under the Household Registration System (hukou)-were gradually relaxed, and rural farmers were encouraged to "leave the land but not the countryside" in order to participate in the countryside's newly-formed township and village enterprises (TVEs). The innovative emergence and success of TVEs was in part an outcome of the decentralization of rule promoted by the Party-State in the reform period, although their origins extend to the Cultural Revolution's fostering of local governmental initiatives (Anderson 2010:76). This earlier effort shifted resources and discretion to communities, localities, and lower levels of government to encourage localized strategies of growth and development (Shue 2010:45-6).

\footnotetext{
${ }^{2}$ The Great Leap Forward's restructuring of land use followed a policy of complete land collectivization (1955-56), which came within a few years of the original redistribution of land (1947-1953).
} 


\section{JOURNAL OF WORLD-SYSTEMS RESEARCH}

The success of TVEs, moreover, was partly an outcome of the entrepreneurship of rural farmers and farmer-migrants. The Chinese peasantry had never been "a listless, sullen rump of the class it had once been, as in Russia. It was neither tired not disaffected, but full of potential energy, waiting to be released" (Anderson 2010:76). Sponsored and subsidized by local governments, TVEs developed into a hybrid form of small-scale industrial enterprises that fell between state, collective and private property. They developed with great speed and dramatic success by harnessing the entrepreneurial energy of farmers. Those who migrated from the countryside often did so to work within the countryside TVEs where employment more than quadrupled from 28 million to 135 million. Rural industrial output increased at an annual rate of $20 \%$, and TVEs' share of national GDP increased from $6 \%$ at the onset of reforms to $26 \%$ in the mid-1990s (Anderson 2010:84). Rural migration to TVEs created powerful synergies between the pursuit of competitive economic growth by local governments and the exercise of entrepreneurship by rural households in non-agricultural sideline activities. These synergies injected sustained dynamism to Chinese economic growth; they also promoted sustained upward social mobility of China's rural population. Between 1989 and 2005, using 2003 as a baselineyear, the yearly real per capita income of rural residents rose by $300 \%$. As real rural purchasing power increased, rural per capita consumption of meat, eggs, and fish, increased by 50\%-100\% between 1985 and 1998, as did consumption of consumer durables like washing machines, refrigerators, color TV sets, and motorcycles (Wright 2010:115).

To these positive effects of growth without rural dispossession, there are of course negative instances of effects of "decentralized accumulation" (Lee 2010) by local government officials over-ambitious to fulfill Central Government growth targets. Although technically land is under the collective ownership of the village and subject to the control of Village Committees (VCs), expropriation of farmland by township and county level governments - ostensibly for development purposes - often occurred (Wright 2010:125). Premier Wen Jiabao's speech in 2005 highlighted how the "reckless occupation" and appropriation of agricultural land by local governments for development purposes created large numbers of landless farmers which threatened sustainable development of the countryside (cited in Ho 2010:101). Policies that prioritized economic growth contributed to abuses at the local government level, including environmental degradation, abusive taxation by local cadres, widespread official corruption, and confiscation and sale of collective rural land.

To counter these abuses and to prevent social unrest within villages, the Party-State introduced 'rule by law' in the mid-1980s and encouraged Chinese citizens to take grievances against local cadres to the courts (Zweig 2010:124). China's rural multitudes responded to 'rule by law' with street protests and collective petition efforts between 1993 and 2005 involving millions of farmers. The number of "collective incidents" of unrest nation-wide jumped tenfold from 8,706 in 1993 to 87,000 in 2005 , with $40 \%$ of these occurring in the countryside (Li and O'Brien 2010:86). In 2005, out of the 13 million collective petition efforts recorded nation-wide, some $60-80 \%$ were initiated by farmers in relation to land disputes (Wright 2010:118). Protest leaders at the village level include well-established opinion leaders with moral authority in their community who use their knowledge of central regulations to frame grievances against violations of these regulations by local officials ( $\mathrm{Li}$ and O'Brien 2010:88-92). An extremely powerful "rights-consciousness" spread throughout the countryside, reflecting "policy-based resistance" in which villagers have used the law to their advantage (Zweig 2010:128). Such protests activated by village leaders mobilizing "rights-conscious" farmers suggest that the Maoist legacy of rural militancy and resistance against local level corruption is alive and widespread. At the same time, 
although the countryside deeply resents the abuse of power by local officials, it retains its trust in the policies of the Party-State. As Li and O'Brien (2010:95) observe, village protest leaders remain "confident in the Center's ability to deliver justice" (see also Wright 2010; Shue 2010).

How has the Party-State responded to these rural claims and to its own concerns over instabilities in the countryside? To placate farmers' assertions that local taxes were being misappropriated and to stabilize rural society, by 1988 the CCP promoted direct elections for Villagers' Committees (VCs), and particularly for the director of these Committees, in order to shift economic authority to local levels (Zweig 2010:123-4). As a result, village elections have become more meaningful, especially after a 1998 law empowered Village Assemblies to discuss and decide village expenditures and revenues, plot allocations, family planning actions, and collective contracts. By 2003 it appeared that 40\% of China's villages were operating in accordance with central policies. Protests and petition efforts revolving around excessive taxation have virtually disappeared since the tax reforms of the first years of the new millennium. In general, there is a consensus among researchers on rural tax and land conflicts that "what has encouraged peasants to undertake collective action...has been their belief that local authorities have not been implementing central policies designed to protect peasants' interests" (Wright 2010:117-19). At the same time, an increasingly rights-conscious peasantry is forcing the Chinese Party-State to be more cognizant of its historical role and responsibilities towards the peasantry.

Farmers' interests however are undermined by the "deliberate institutional ambiguity" in China's contemporary land rights system inherited from the Collectivist era of 1956-78 (Ho 2010:103). At that time a three-tier system of land administration including the People's Commune, the Production Brigade, and the Production Team prevailed. After the initial Land Reform (1947-53), the 1962 Four Fixes movement granted permanent ownership of land, labor, tools and animals to the Production Team (the lowest collective level) but there was no accompanying nationwide cadaster. Nor were titles to land ownership issued to villagers in any systematic way. All this made the question of farmers' rights to use of collective land rest on ambiguous terrain. De-collectivization in the mid-1980s replaced the three-tier system of administration under Collectivization with another three-tier system represented by the Township/Town, the Administrative Village, and the Natural Village. And the Collective period's policy of frequently requisitioning land from the Production Team (what is today the Natural Village) without proper procedures and financial compensation reappeared to some extent in the practices of local governments during the late reform period. Local governments have sought to generate revenues for economic growth through commercialization of suburban land. The majority of land-ownership disputes in the 1990s and beyond were concentrated in the peri-urban zone, and these land disputes were related to commercialization of suburban land and urban sprawl (Ho 2010:102; Zweig 2010:131). A further complication on farmers' claims to land use-rights was "the vague definition of collective ownership and therefore, the collective's inability to protect and represent its members" (Ho 2010:105). The collectivist period also introduced the largely unresolved issue of customary land-use rights, which included rights to forest, grassland and wasteland, especially in frontier zones inhabited by ethnic minorities (Ho 2010:116). ${ }^{3}$ As China "goes West" these customary rights suffer from varying degrees of infringements by the Party-State's development priorities for China's western and interior regions.

\footnotetext{
${ }^{3}$ For instance, mountain tribes in Yunnan have used forests as a community right, and the Mongols and Kazakhs in Inner Mongolia and Xinjiang have traditionally recognized community grazing rights on land.
} 


\section{JOURNAL OF WORLD-SYSTEMS RESEARCH}

In sum, on the face of it, some collectivist legacies appear to militate against the East Asian developmental path. The diversity in land management policies at every administrative level following decentralization of authority during the reform period enables Loren Brandt and his collaborators to remark that central or regional policymakers are not the final arbiters in land management issues (2002:81-2). Local government officials successfully sidestep centrally proclaimed edicts. They are able to do so in the absence of a general legal framework for land rights. To counter such local governmental autonomy, central policy makers have opened legal windows for redress. Farmers take local cadres to court and use customary claims on land use to protest abuses at the local level. Insofar as legal proceedings often work against farmers' interests, this tends to produce more social unrest.

To address unrest in the countryside, central authorities abolished the rural land tax on farmers and created a hybrid and ambiguous property rights structure that has not hampered China's agricultural development or its food security. The institutional ambiguities in China's land rights system have not fostered fundamental challenges to the present land ownership structure. No widespread claims for private, common or other forms of rural land ownership have arisen since the mid-1980s, in part because the bulk of investments diverted to nonagricultural uses continue to bring benefits to villagers. Even in the highly urbanized coastal provinces, rural settlements and rural roads together accounted for nearly $64 \%$ of the land allocated to nonagricultural use in the coastal provinces (Ho and Lin 2004a:85). And the newer institution of Village Committees appears to empower village level democratic institutions. If rural discontent over land appropriations by local party cadres remains, it co-exists with a faith in the Party-State's ruling ideology of a harmonious society. Li's study of rural China argues that "the trust in the central state felt by many villagers suggests that the regime still has some breathing space because dissatisfaction with lower levels has not yet generated demands for farreaching political reforms" (2004:229). Rural unrest is widespread: at the same time, it is not deep enough for farmers to demand a transformation of the existing rural land use structure.

Although growing spatial inequalities resulting from over-investment in coastal zones have been a consistent feature of China after the mid-1980s, these inequalities are not irreversible. The new shift in policy priorities away from coastal development to development of the interior western regions is a direct response by the Party-State to these growing inequalities. A more balanced pattern of rapid growth over the new Plan period (2011-2015) is central to the "populist orientation" of the Hu-Wen combination since 2002, and this is reflected in direct income subsidies to rural residents and increased public investment in inland and western provinces (Dickson 2010:34). This has the potential to reduce inter-regional and rural-urban inequalities over the new Plan period and beyond. Using 2004 data, Martin Whyte (2010) has argued that inequalities in China are not perceived by rural Chinese as either unjust or unfair. They are, however, the effect of local accumulation through displacement of farmers from the land. In the recent past, inter-local governmental competition for economic growth often prioritized industrial advancement at the expense of investments in agricultural land. In the process, many farmers have indeed been displaced from the land as the land has been converted into sites for industrial production. But displacement is not the same thing as dispossession from the land. Migrant farmers in the booming provinces of coastal China have in fact "voted with their feet" by returning to the countryside in millions rather than be exploited in the deregulated foreigninvested export-processing zones. But this 'exit' option for migrant farmers is exercised precisely because it is available as an option: no matter how destitute, they have a piece of farm 
land to return to, from which they have not been dispossessed (Lee 2007:204-5; Trichur 2009:124).

\section{Urban Land Relations in post-1978 PRC}

Are the implications for the East Asian development path different when we shift our attention to urban land rights and urban land conflicts in post-1978 China? Since the mid-1980s, Chinese cities have expanded at a fast pace, but this intensified expansion of urbanization has not been accompanied by dispossession of urban residential dwellers from urban land. As in the case of agricultural land, all urban land is owned by the Party-State, and the economic reforms have led to some displacement. But this displacement has mostly been of migrant workers in the cities who are typically denied formal residential rights and whose ad-hoc residential constructions have often been demolished in favor of urban planning priorities (Solinger 1999). For instance, there was considerable displacement of migrant workers from Beijing during the 2008 Olympics. Nevertheless, urban born workers retain many of their privileges inherited from the Maoist period, most notably their claims to an urban hukou that entitles them to live in state-subsidized residential units and find work in urban areas.

Urban working classes have indeed suffered in the course of China's economic reforms. The reform and restructuring of the state-owned enterprises (SOEs) in the mid-1980s was associated with the 'unmaking' of Mao's urban working classes in the 1990s. These reforms of the SOEs have also been seen as the end of the socialist welfare state of the Maoist era, just as the early 1990s were associated with the "shock therapies" that ended the socialist welfare state in the former USSR and some Eastern European societies (Solinger 1999; Lee 2007). However, the differences between the Chinese and Russian or Polish experiences are equally insightful. In China, unlike in Poland or Russia, the restructuring of the SOEs did not lead to the end of the welfare state. Tens of millions of urban workers were indeed laid off and displaced following the dismantling in 1995 of the system of permanent employment (the 'iron rice bowl') that the Maoist regime had offered to urban workers in SOEs. Severe setbacks in urban workers' status and livelihood did accompany the end of the system of "organized dependence" and paternalism characteristic of state-labor relations under state socialism.

At the same time, these dislocations sparked a huge number of collective protests by urban workers against the material and psychological effects of restructuring of SOEs and relocation of workers. During most of the 1990s, urban workers protested against wage and pension arrears, inadequate unemployment and medical allowances, and embezzlement of funds by factory managers. In general, subsistence rights have been at the center of urban workers' protests. Moreover, since the late 1990s urban Chinese protesters, like their rural Chinese counterparts, have made use of the emergent discourse of legal rights to appeal to the PartyState's claim to 'rule by law' (Lee 2007; Lee 2010:60-1; 67-9). It is clear that urban working classes have held the government responsible for mass economic dislocation. It is equally clear that the Party-State has responded to the urban experience of economic dislocation by expanding pension coverage and other social insurance programs. The 1997 Pension Regulations stipulated that both part-time and full-time urban employees would have pension rights. Pension coverage has expanded since the late 1990s from 52 million urban workers in 1990 to 152 million in 2007. Between 1995 and 2007, the number of workers covered by unemployment insurance coverage rose from 82.4 million to 180 million. The 2008 passage of the Social Insurance Law also made room for welfare rights of migrant workers in urban spaces. In short, while China along with 


\section{JOURNAL OF WORLD-SYSTEMS RESEARCH}

Russia and Poland dismantled their socialist welfare states, only the PRC Party-State has, in response to urban worker protests, expanded the urban welfare state into the twenty-first century (Frazier 2010:259-62).

More importantly, the reform and restructuring of the SOEs has displaced workers but not dispossessed state-sector workers from their housing entitlement. There are no signs of homelessness even in the worst hit areas of China's 'rustbelt.' The near universal provision of housing for state workers is central to understanding the stability of the Party-State. "No matter how destitute, they have a home to go back to at the end of the day" (Lee 2007:125-6; Trichur 2009:123-4).

It is true that urbanization has promoted land and property speculation: in 1988 a leasehold market for urban land was created to formally separate land ownership from urban land-use rights of central and municipal governments. In general, the central government's representatives often control and occupy land in the core of the urban areas and maintain proprietary rights over the urban compounds that were the former socialist work units (the danwei). The remainder of the urban land in the city is used by municipal government officials who can lease the use of urban land for a fixed period of time. We may note two outcomes of this newer urban land-use rights regime. First, urban land tenure has indeed been commodified under the new post-1978 regime. Nevertheless, land tenure has not yet been privatized (Hsing 2008:57). Second, commodification of land-use has enabled urban central government officials to transfer land-use rights to newly emerging land development companies. Local municipal officials have also leased out urban land under their jurisdiction to a growing network of land brokers. Driven by a politics of productivity and growth, local officials try to demonstrate their capabilities to the center by making investments in large-scale development projects through progrowth coalitions with local real estate developers and entrepreneurs (Li and Sheffrin 2008; Dickson 2010:28; Lee 2010:61; Zweig 2010:131-2).

Such "decentralized accumulation" (Lee 2010:75) has accelerated transfers of urban land-use rights, overheated urban real estate markets, and generated unsustainable booms in private housing prices. Inadequate mechanisms for supervision of the current land leasing system and speculative land-intensive investments in condominiums, hotels, luxury resorts and the like, distort the land saving legacies of the East Asian developmental path. On the other hand, the potential for redistributive and equalizing taxation remains very high in urban China: in 2002 property tax and urban land-use tax accounted for only 3\% and $1 \%$ respectively of local governments' tax revenues ( $\mathrm{Li}$ and Sheffrin 2008:80). In the past year the Party-State has attempted to deflate overheated real estate prices through its trial property tax project in Shanghai and Chongqing (Anderlini 2011). Zweig (2010:131-2) observes that commercialization of suburban land remains "one of the most incendiary issues in Chinese society" in the absence of adequate legal institutions to regulate suburban housing markets. In this context Wen Jiabao's March 2011 national address has sent an unambiguous directive to local governments, putting local officials on notice that they would incur a "firing offense" for failure to advance the Twelfth Five Year Plan's priorities for building 36 million state-subsidized urban housing units over the plan period (2011-2015). As the chief China economist for Standard Chartered Bank says, "The quiet message to developers is clear: you've made your money, now it is time to serve the country" (quoted in Anderlini 2011).

It is also relevant to note that despite the rapid rate of net rural-urban migration of more than 14 million per year, China has largely avoided creating those huge peri-urban slums that proliferate in cities of the global South and which Mike Davis (2006) associates with the 
imposition of neoliberal Structural Adjustment Policies. All over the global South, the withdrawal of the state from its commitments to urban and rural development was also associated, especially after the mid-1980s, with the widespread growth of the informal sector and the weakening of available urban social infrastructure. China's relative autonomy from external pressure allowed it some latitude in its choice of economic reforms, and its urban planning has supported small- to medium-sized cities and labor-intensive industrialization in the countryside rather than concentrating development in larger megalopolises like Shanghai. This has helped China to absorb off-season farm laborers without agricultural labor shortages so that China's development strategy has remained aligned with the general East Asian land-saving and laborintensive developmental path. It has also meant enormous savings on infrastructure. Emphasizing rural industrialization and slowing urbanization has also contributed to social stability (Pomeranz 2008:93-4). There is little comparison possible between Davis's "planets of slums" that dot the landscape of the global South and the Middle Kingdom's relatively regulated urban environment. If the threat of urban dystopia is real enough, it is also within the regulatory capacities of the Chinese Party-State to adequately address these emerging problems associated with urbanization.

The Party-State's active interest in land and housing relations was signaled in the March 2011 address to the nation by Premier Wen Jiabao. By 2015 the Party-State plans to have 20\% of the 218 million urban households living in state-subsidized apartments, up from an estimated $11 \%$ at the end of 2007. Some RMB1300 billion was allotted in 2011 alone for the building of 10 million subsidized apartments. The Plan's top priority is to rein in speculation and inflation in residential real estate markets and keep a watchful eye on local officials. The state-owned banks have been banned from giving mortgages to people with more than one property. The banks have also been exhorted to work with local governments to help channel investment funds into lowincome housing projects (Anderlini 2011). These measures indicate the will and determination of the Party-State to bring under greater central control the land speculation effects of "decentralized accumulation" in urban spaces. Average transaction prices for land sales across China fell 51\% since the start of 2011. Land sales are now actively discouraged as a source of local governments' finances. Insofar as land sales continue, the new central policy requires that at least $70 \%$ of the receipts from all local land sales are invested in different forms of subsidized housing for urban dwellers (Sender and Anderlini 2011). The 2008 Social Insurance Law provides further evidence of the Party-State's concerns for urban welfare. The outcome of the next few years will reveal the extent to which the Party-State has succeeded in prioritizing urban livelihood in the aftermath of the 2008-9 global financial crises.

\section{Environmental Legacies}

I close this section with an overview of China's environmental legacies and transformations. Elvin has argued that China's impressive pre-modern economic growth was often pushed beyond environmentally sustainable limits. He links the intensified exploitation of nature to "the drive to acquire the means of political, economic, and military power, at state and societal levels" (1996:733-56). Elvin's narrative, however, leaves out many of the complexities that emerge when environmental projects and policies are seen as embedded in a late Imperial statecraft that had to address concerns of domestic order beyond just military matters. Concerns of domestic order and stability throughout the Chinese empire were central not just in creating huge food

buffer stocks in the form of "ever-normal granaries" (Wong 1997); but also in reproducing and 


\section{JOURNAL OF WORLD-SYSTEMS RESEARCH}

managing late Imperial China's ecological and economic differences. The shift of the capital of the Ming Dynasty to Beijing on the North China Plain was followed by the building of the Grand Canal. As Pomeranz (2009:123-7) argues, this not only ensured shipments of southern grain to Beijing; it also put in place a political and economic orientation driven by social priorities that lasted for over four hundred years until European incursions and social unrest undermined these policies and priorities. Three of these social priorities stand out as long-term continuities.

First, China's social priorities helped keep large numbers of people in the countryside and encouraged rural industry. It continues to be part of contemporary Chinese statecraft which exhorts farmers to "leave the land, but not the countryside," and invests in TVEs and rural development. By channeling migratory labor flows into rural TVEs, such an approach to development has controlled and regulated the pace of rural-urban migration as well as the rate of change of urbanization. One consequence of this regulated approach to urbanization is that unlike most of the global South, the growth of cities has not been accompanied by proliferation of urban slums and the pressures they exert on urban infrastructure.

Second the PRC's emphasis on social priorities helped prop up ecologically vulnerable regions in the north with large minority populations (in Manchuria, Tibet, and Xinjiang) through low land-tax rates, subsidies for family farming, and a strong civilian granary system landscape and economy, reshaping them with considerable gradualism. By contrast, the elites of the richer Yangzi delta were taxed to support the movement of the Grand Canal waters to the poorer north. The contemporary 'go west' policy may appear to go against such late imperial statecraft insofar as the western regions of China are modernized. As the dominant Han-ethnic settlements increase in the western regions they also create social tensions with China's minority populations in these regions. However, the Twelfth Five Year Plan's gradualist approach to modernization of the interior regions and greater inclusion of minorities in state-led development of the interior regions may moderate inter-ethnic tensions.

Third, the PRC's promotion of rural market-based agricultural and other economic activity as the means for reproducing family life supported independent farming households and helped prevent rural displacement. Markets were a means to facilitate the Confucian good life the ability to marry, bury parents, and celebrate the annual ritual cycle. Chinese statecraft in the reform era appears to have fully revived market-based economic activity after its eclipse between 1949 and 1978.

These continuities that framed late-imperial Chinese policies and reproduced East Asian developmental priorities into the post-revolutionary period were disrupted in the aftermath of Western incursions into China and in the course of the Taiping Rebellion (1851-1864). Between 1850 and 1930, Chinese rulers began to promote industrial development in the heavily commercialized, coastal areas. River-control funds were sharply reduced, and money was diverted to protect strategic coastal areas. Interior areas experienced a downward ecological spiral. Between 1930 and 1949, technocratic engineering responses dominated, and large, multipurpose dams were proposed alongside proposals for large-scale industrialization. However, populist responses encouraged implementation of some labor-intensive adjustments to restore farming, handicrafts, and petty commerce/sideline activities. Although the Maoists initially responded favorably to mass populist aspirations, after 1949 they developed greater affinity for technocratic and military approaches to economy and environment, as is reflected in their construction of the Three Gorges dam on the Yangzi River. The post-1978 Deng regime continued to prefer technocratic, engineering solutions to China's environmental needs. However, it also favored market-based development by small farmers and entrepreneurs. 
What is the environmental balance sheet in relation to the East Asian developmental path? Pomeranz points out that "the continuity that seems to be fading away fastest is the longstanding tendency to tread cautiously in minority regions" (2009:153). There is some truth in this claim. Second, the strong statist preference for capital-intensive and mega- projects continues. Both these tendencies go against the East Asian developmental path. However, there are other signs that we may note as well. During Wen Jiabao and Hu Jintao's tenure, the emphasis has been increasingly on balanced growth with harmonious sustainable ecological development. China's "extraordinary surge" of investments in wind turbines, solar panels and low-carbon technology grew $76 \%$ over the preceding year to $\$ 11.5$ billion in the second quarter of 2010 , which was more than double the comparable investments made by either the United States or Europe. In 2010, China planned to install a record 18 gigawatts of wind power capacity (Bloomberg 2010). More recently, China and Germany, the biggest economies of Asia and Europe, signed $\$ 15$ billion worth of trade deals for joint collaboration in the development of green technologies in energy saving, smart electricity transmission, carbon capture technology and sustainable traffic systems in the PRC. As Peel and Anderlini (2011) underscore, these deals represent "a big step by China...to deal with its huge environmental problems and reinforce the emphasis of its latest Five Year Plan on sustainable development". Finally, despite the persistence of top-down technocratic projects, it is likely that heavy reliance on local watersupply projects run by ordinary villagers will persist alongside the valorization of rural life. The resilience of the populist current, embodied in many "small-scale, locally managed irrigation works, which have thus far survived the decline in local cadres' ability to command people's labor," are "among the most impressive and unusual achievements of Chinese ecological management” (Pomeranz 2009:153, 142).

\section{CONCLUSION}

I have pointed to the changes in rural and urban land-use rights during the conjuncture of the mid-1980s when the Chinese Party-State banked on the popularity of economic reforms to push forward the reform momentum. The Chinese Communist Party completed the de-collectivization of the countryside, restructured state-owned enterprises to make them compete better, and it successfully created township and village enterprises and export-oriented special economic zones in coastal provinces to absorb migrant farm labor. These processes of social, economic and ecological transformation created substantial upward social mobility for millions of rural Chinese who, despite many instances of local corruption and infringements of central directives to rule by law, continue to retain trust in the Party-State's claims to legitimacy. These processes also created rural-urban income inequalities and inter-regional income inequalities. At the same time the gradual relaxation of the hukou system opened numerous opportunities for farmers to benefit from China's economic reforms. These benefits have not come at the cost of losing their access to farm land plots given to them by the second land reform's Household Responsibility System. Farmer-migrant laborers who seek work in China's booming coastal special economic zones and who often find themselves over-exploited also often vote with their feet. They have been successful in doing so because they have been able to take local cadres to the courts. When migrants fail, they return to the countryside where they still have a piece of land to which they can return. What Farshad Araghi (2000) calls the great global enclosure of our times remains an unfinished project in rural China. Incomplete proletarianization persists - not accumulation by dispossession of rural land. Second, laid-off urban workers who suffer from unemployment still 


\section{JOURNAL OF WORLD-SYSTEMS RESEARCH}

have durable housing rights to fall back upon. However cramped their urban spaces, they are not completely destitute. The evidence of displacement in China is not evidence for Harvey's (2005) claim that accumulation by dispossession dominated post-1978 developments in China.

Adjustment processes are always drawn out. Karl Polanyi reminds us that that the rate of change is often a more important consideration than the direction of change (2001:39). In China the post-1978 direction of change has revived market-economy traditions. The rate at which economic change has unfolded has been controlled and regulated by the Party-State. Gradualism and experimentation with welfare-oriented growth policies continue to dominate Party-State priorities. Sustained economic growth rates, and local level corruption and inefficiencies associated with rapid growth, have indeed caught the attention of many observers. As Stephen Mihm (2008:278) points out, "to see China today is to glimpse, in a distant mirror, the nineteenth century American economy in all its corner-cutting, fraudulent glory," of which Chicago is probably a good example. All kinds of economic and environmental excesses accompanied economic growth in the U.S. during the late nineteenth and early twentieth centuries. But unlike the evolution of U.S. business enterprises in the late nineteenth century in the direction of a small number of giant multi-unit, multinational vertically-integrated capitalist corporations wielding monopoly control over markets, the evolution of business enterprises in contemporary China is dominated by a large number of small-scale, competitive, market economy based firms regulated by the Party-State.

It is also not clear whether the direction of change spearheaded by Chinese farmers has lost its momentum. The most momentous transformations associated with the Deng reforms were in fact shaped by different varieties of farmers' movements from below (Zhou 1996: 46-71). The success of these movements in making the Party-State implement reforms in the late 1970s indicates not only the power of farmers as political entrepreneurs, but also their role as successful rural economic entrepreneurs whose rising productivity determined the form taken by the TVEs. It is fair to suggest that China's farmer-based economic growth will continue to reproduce an entrepreneurial vector that is small-scale, family-based, place-based and kinship-based. Although inequalities among rural residents has risen dramatically since the reforms, it may be starting to decline again, at least in the more successful regions, as wage-incomes become more diffused across an increasingly industrialized countryside. The greatest inequalities in China are between different communities and regions rather than between households in a given place (Pomeranz 2009:137).

Giovanni Arrighi (2007:359-60) has argued that China's Party-State, unlike capitalist states elsewhere, does not represent the interests of either domestic or foreign capitalists. And Perry Anderson (2010) has drawn attention to the enlightened Party leadership that navigated China through unpredictable reform waters in ways distinct from that of Soviet leadership in the late 1980s and beyond. Like the Ming and Qing dynasties of Imperial China, the contemporary Chinese Party-State is sharply focused on problems of governance and legitimacy. Since late 2002 there has been a shift from the earlier focus of the Party on economic growth to a newer focus on redistributing the results of economic growth by raising domestic consumption levels and agricultural incomes while reducing urban-rural income differentials and expanding urban welfare programs. The Party-State appears acutely sensitive to concerns of farmers regarding violations of land-use rights. As Pomeranz (2009:137) observes, protecting subsistence, encouraging the spread of best economic practices, and providing support for rural family life, were not only concerns of traditional Chinese statecraft, they remain key concerns of the contemporary Party-State. The Party-State is even more sensitive to concerns of the unemployed 
and laid-off urban working classes. At a time when neoliberal policies continue as the 'default mode' in much of the global North the re-creation of the foundations of a people's welfare state dominates the Twelfth Five Year Plan's priorities. How far and in what directions China's leadership moves forward with these priorities remains to be seen.

\section{REFERENCES}

Anderlini, Jamil. 2011. "Housing subsidies at heart of Beijing's 'new deal." Financial Times, May 30. Retrieved June 30, 2011 (http://www.ft.com/cms/s/0/92c6ff5e-8b9e-11e0-a72500144feab49a.html\#ixzz1QnAoGK7E).

Anderson, Perry. 2010. “Two Revolutions: Rough Notes.” New Left Review 61: 59-96.

Araghi, Farshad. 2000. "The Great Global Enclosure of Our Times: Peasants and the Agrarian

Question at the End of the Twentieth Century." Pp. 145-160 in Hungry for Profit: The Agribusiness Threat to Farmers, Food, and the Environment, edited by F. Magdoff, J.B. Foster, and F.H. Buttel. New York: Monthly Review Press.

Arrighi, Giovanni. 1994. The Long Twentienth Century: Money, Power, and the Origins of our Times. London: Verso.

-----. 2007. Adam Smith in Beijing: Lineages of the Twenty-first Century. London: Verso.

Arrighi, Giovanni and Lu Zhang. 2010. "Beyond the Washington Consensus: A New Bandung?" Forthcoming in Globalization and Beyond: New Examinations of Global Power and its Alternatives, edited by Jon Shefner and Patricia Fernandez-Kelly. State College, PA: Penn State University Press.

Bloomberg Business Week. 2010. "China Surges Past U.S., Europe in Clean-Energy Asset Financing." Retrieved August 1, 2010 (http://www.businessweek.com/news/2010-0713/china-surges-past-us-europe-in-clean-energy-asset-financing.html).

Brandt, Loren, Jikun Huang, Guo Li, and Scott Rozelle. 2002. "Land Rights in Rural China: Facts, Fictions and Issues." The China Journal 47: 67-97.

Coulter, John. 2010. "Crude act glorified by a soft term." China Daily, November 18, p. 9.

Davis, Mike. 2006. Planet of Slums. London: Verso.

Derlugian, Georgi. 2011. "The Post-Soviet Recoil to Periphery." Pp. 209-234 in Aftermath: A New Global Economic Order?, edited by Craig Calhoun and Georgi Derlugian. New York: Social Science Research Council and New York University Press.

Dickson, Bruce. 2010. "Dilemmas of Party Adaptation: The CCP's Strategies for Survival.” Pp. 22-40 in Chinese Politics: State, Society and the Market, edited by Peter Hays Gries and Stanley Rosen. London: Routledge. 


\section{JOURNAL OF WORLD-SYSTEMS RESEARCH}

Eberlein, Xujun. 2009. “China: Democracy or Confucianism?” Pp. 270-273 in China in 2008: A Year of Great Significance, edited by Kate Merkel-Hess, Kenneth Pomeranz, and Jeffrey N. Wasserstrom. New York: Rowman \& Littlefield Publishers, Inc.

Elvin, Mark. 1973. The Pattern of the Chinese Past. Stanford, CA: Stanford University Press.

-----. 1998. “The Environmental Legacy of Imperial China.” The China Quarterly 156: 733-756.

Frazier, Mark. 2010. "Popular Responses to China's Emerging Welfare State." Pp. 258-274 in

Chinese Politics: State, Society and the Market, edited by Peter Hays Gries and Stanley Rosen. London: Routledge.

Harvey, David. 2005. A Brief History of Neoliberalism. Oxford: Oxford University Press.

Ho, Peter. 2010. "Contesting Rural Spaces: Land Disputes, Customary Tenure and the State." Pp. 101-122 in Chinese Society: Change, Conflict and Resistance, edited by Elizabeth Perry and Mark Selden. London: Routledge.

Ho, Samuel P.S., and George C. S. Lin. 2004a. "Converting Land to Nonagricultural Use in China's Coastal Provinces: Evidence from Jiangsu.” Modern China 30(1): 81-112.

-----. 2004b. "Non-Agricultural Land Use in Post-Reform China." The China Quarterly 179: 758-781.

Hsing, You-tien. 2008. "Socialist Land Masters: The Territorial Politics of Accumulation.” Pp. 57-70 in Privatizing China: Socialism from Afar, edited by Li Zhang and Aihwa Ong.. Ithaca, NY: Cornell University Press.

Jiabao, Wen. 2011. "How China Plans to Reinforce the Global Recovery." Financial Times, June 23. Retrieved June 25, 2011 (http://www.ft.com/cms/s/0/e3fe038a-9dc9-11e0-b30c00144feabdc0.html\#ixzz1QKs9G6bq).

Lee, Ching Kwan. 2007. Against the Law: Labor Protests in China's Rustbelt and Sunbelt. Berkeley: University of California Press.

-----. 2010. "Pathways of Labor Activism." Pp. 57-79 in Chinese Society: Change, Conflict and Resistance, edited by Elizabeth Perry and Mark Selden. London: Routledge.

Li, Bei, and Sheffrin, Steven M. 2008. "Tax Tensions: Struggles over Income and Revenue”. Pp. 71-86 in Privatizing China: Socialism from Afar, edited by Li Zhang and Aihwa Ong. Ithaca, NY: Cornell University Press.

Li, Lianjiang. 2004. "Political Trust in Rural China." Modern China 30(2): 228-258.

Li, Lianjiang, and Kevin J. O’Brien. 2010. "Protest Leadership in Rural China.” Pp. 85-108 in Chinese Politics: State, Society and the Market, edited by Peter Hays Gries and Stanley Rosen. London: Routledge.

McNeill, William H. 1982. The Pursuit of Power: Technology, Armed Force, and Society since A.D.1000. Chicago: The University of Chicago Press.

Mihm, Steven. 2008. “A Nation of Outlaws." Pp. 277-282 in China in 2008: A Year of Great Significance, edited by Kate Merkel-Hess, Kenneth Pomeranz, and Jeffrey N. Wasserstrom. New York: Rowman \& Littlefield Publishers, Inc.

Peel, Quentin, and Jamil Anderlini. 2011. "China and Germany launch green initiative." Financial Times, June 28. Retrieved June 29, 2011 (http://link.ft.com/r/73UJGG/DW4JP0/XTLKOQ/C5266Y/5COJGP/7V/h?a1=2011\&a2=6 \&a3=29).

Perry, Elizabeth, and Mark Selden. 2010. "Introduction: Reform and Resistance in Contemporary China." Pp. 1-30 in Chinese Society: Change, conflict and resistance, edited by Elizabeth Perry and Mark Selden. London: Routledge. 
Polanyi, Karl. [1944] 2001. The Great Transformation: The Political and Economic Origins of Our Time. Boston: Beacon.

Pomeranz, Kenneth. 2009. "The Transformation of China's Environment, 1500-2000.” Pp. 118164 in The Environment and World History, edited by Edmund Burke III and Kenneth Pomeranz. Berkeley: University of California Press.

Pomeranz, Kenneth. 2008. "Chinese Development in Long-Run Perspective." Proceedings of the American Philosophical Society 152(1): 83-100.

Shue, Vivienne. 2010. "Legitimacy Crisis in China?" Pp. 41-68 in Chinese Politics: State, Society, and the Market, edited by Peter Hays Gries and Stanley Rosen. London: Routledge.

Selden, Mark. 1995. “Yan'an Communism Reconsidered.” Modern China 21(1): 8-44.

Sender, Henny, and Jamil Anderlini. 2011. "China land price fall threatens local finances." Financial Times, June 1. Retrieved July 4, 2011 (http://www.ft.com/cms/s/0/82e299dc8b9d-11e0-a725-00144feab49a.html\#ixzz1OSXkYzSr).

Solinger, Dorothy. 1999. Contesting Citizenship in Urban China: Peasant Migrants, the State, and the Logic of the Market. Berkeley: University of California Press.

Sugihara, Kaoru. 2003a. "East Asian Path." Economic and Political Weekly, 21-27 August 2004: 3855-858.

------. 2003b. "The East Asian Path of Economic Development: A Long-Term Perspective." Pp. 78-123 in The Resurgence of East Asia: 500, 150, and 50 Year Perspectives, edited by Giovanni Arrighi, Takeshi Hamashita, and Mark Selden. London: Routledge.

Trichur, Ganesh K. 2009. "Internal Migration in Mainland China: Regional and World-Systemic Aspects." Pp. 104-129 in Globalization and Emerging Societies: Development and Inequality, edited by Jan Nederveen Peiterse and Boike Rehbein.. New York: Palgrave Macmillan.

Wong, R. Bin. 1997. China Transformed: Historical Change and the Limits of European Experience. Ithaca, NY: Cornell University Press.

------. 2011. "Chinese Political Economy and the International Economy: Linking Global, Regional, and Domestic Possibilities." Pp. 149-163 in Aftermath: A New Global Economic Order?, edited by Craig Calhoun and Georgi Derlugian. New York: Social Science Research Council and New York University Press.

Whyte, Martin King. 2010. "Do Chinese citizens want the government to do more to promote equality?" Pp. 129-159 in Chinese Politics: State, Society and the Market, edited by Peter Hays Gries and Stanley Rosen. London: Routledge.

Wright, Teresa. 2010. “Tenuous Tolerance in China's Countryside.” Pp. 109-128 in Chinese Politics: State, Society and the Market, edited by Peter Hays Gries and Stanley Rosen. London: Routledge.

Zhengyue, Hu. 2010. "China wants mutual trust and benefit." Editor's interview with $\mathrm{Hu}$ Zhengyue, China's Assistant Foreign Minister in Charge of Asian Affairs. In China Daily, 12 November.

Zweig, David. 2010. "To the courts or to the barricades: Can New Political Institutions Manage Rural Conflict?" Pp. 123-147 in Chinese Society: Change, Conflict and Resistance, edited by Elizabeth Perry and Mark Selden. London: Routledge. 